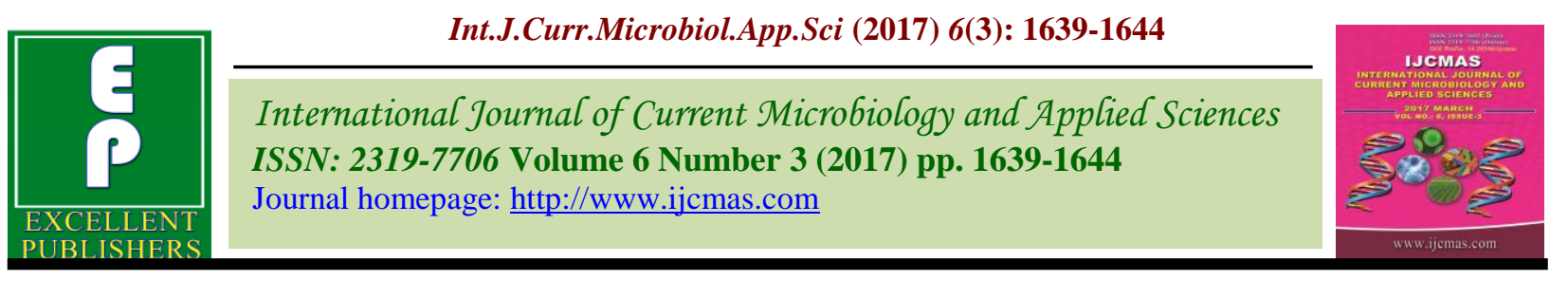

Original Research Article

https://doi.org/10.20546/ijcmas.2017.603.189

\title{
Studies on the Compatibility of Biocontrol Agents with Certain Fungicides
}

\author{
Praful Kumar* and S.S. Mane
}

\author{
Dr. Panjabrao Deshmukh Krishi Vidyapeeth, Akola, 444104 (MS), India \\ *Corresponding author
}

\begin{tabular}{|c|c|}
\hline & A B S T R A C T \\
\hline $\begin{array}{l}\text { Trichoderma viride, } \\
\text { T. harzianum, } P \text {. } \\
\text { fluorescens, } \\
\text { Fungicides, } \\
\text { Compatibility. }\end{array}$ & \multirow{3}{*}{$\begin{array}{l}\text { Compatibility of biocontrol agents viz., Trichoderma viride, T. harzianum and } P \text {. } \\
\text { fluorescens were studied with four Fungicides viz., Thiram @0.3\%, Carbendazim @0.1\%, } \\
\text { Captan @ } 0.3 \% \text {, fosetyl AL @ } 0.2 \% \text {, in favour of tolerance to fungicides. It was indicated } \\
\text { that radial growth of fungal biocontrol agent Trichoderma viride was significantly } \\
\text { inhibited }(100 \%) \text { with Thiram }(0.3 \%) \text { and Carbendazim }(0.1 \%) \text {. Growth of } T \text {. harzianum } \\
\text { was also } 100 \text { per cent inhibited with Carbendazim }(0.1 \%) \text {. Whereas, both fungal biocontrol } \\
\text { agents had recorded compatible with Fosetyl AL }(0.2 \%) \text {, which have less }(57.59 \% \text { and } \\
1.3 \%) \text { inhibitory effect on growth of } T \text {. viride and } T \text {. harzianum respectively. The bacterial } \\
\text { bioagent viz., } P \text {. fluorescens was found to be more compatible with Carbendazim }(0.1 \%) \\
\text { and Fosetyl Al }(0.2 \%) \text {. Hence, fungicide contamination at given concentration in soil will } \\
\text { not affect their effectiveness. Moreover, the fungicide tolerance ability broadened the use } \\
\text { as these biocontrol agents in integration with fungicides can be applied for the } \\
\text { management of soil borne plant pathogens under integrated disease management. }\end{array}$} \\
\hline Article Info & \\
\hline $\begin{array}{l}\text { Accepted: } \\
22 \text { February } 2017 \\
\text { Available Online: } \\
10 \text { March } 2017\end{array}$ & \\
\hline
\end{tabular}

\section{Introduction}

Soil-borne plant pathogens are highly destructive and cause severe yield losses to all kinds of crops. Some soil borne fungi are difficult to eradicate because they produce resting structures like sclerotia, chlamydospores or oospores for their survival for a longer period of time under adverse environmental conditions (Baker and Cooke, 1974).Control of plant diseases by the use of antagonistic microorganisms can be an effective means (Cook and Baker, 1983). A large number of plant diseases have been successfully controlled through fungal and bacterial antagonists (Sahebani and Hadavi, 2008; Federico et al., 2007; Cook and Baker, 1983; Campbell, 1989; Vidhyasekaran et al., 1997). Trichoderma species have been used in the management of crop plant diseases.
Trichoderma is a genus of asexually reproducing fungi that is present in all types of soils. Many species of Trichoderma have multiple strategies for fungal antagonism, and indirect effects on plant health (such as plant growth promotion effects and fertility improvements) also vary. Several strains of Pseudomonas also have been reported to suppress soil-borne diseases caused by fungal pathogen (O'Sullivan et al., 1992; Weller, 1988). Use of fungicides for the control of soil borne diseases is costly and also produces environment and health hazards to human and adversely affects the beneficial microorganisms in soil (Dluzniewska, 2003). Hence integrate use of fungicides and biological agents for the management of soilborne diseases is efficient and ecofriendly. 
Supplementation of fungicides at reduced rates in combination with biocontrol agents has significantly enhanced disease control, compared to treatments with biocontrol agent alone (Frances et al., 2002; Buck, 2004). The objectives of the present study is to test the growth of different biocontrol agents with commonly used fungicides at different concentrations under in vitro conditions for the control of soil borne plant pathogens.

\section{Materials and Methods}

In vitro studies were carried out under aseptic conditions. All the isolation and inoculation work were carried out in laminar air flow. The laminar air flow platform was sterilized by glowing ultraviolet light for half an hour prior to commencement of work. The glasswares such as Petri plates, beakers, conical flasks and test tubes were sterilized in hot air oven at $180^{\circ} \mathrm{C}$ for 1 hour and media were sterilized in autoclave at $121.6{ }^{0} \mathrm{C}, 15 \mathrm{lbs} / \mathrm{inch}^{2}$ for 15 minutes.

\section{Screening of Trichoderma spp with fungicides}

Compatibility of Trichoderma harzianum and T. viride with four fungicides viz., Thiram @ 0.3\%,Carbendazim@0.1\%,Captan@0.3\%, fosetyl AL @0.2\%) were tested by using "Poison Food Technique". The requisite amount of each fungicide based on active ingradient was added to an autoclaved potato dextrose agar to obtain the desired concentrations of all fungicides. The same medium without the fungicide served as control. The medium was poured into $90 \mathrm{~mm}$ Petri plates in 3 replicates and after solidification, each plate was inoculated with a $5 \mathrm{~mm}$ mycelial disc of Trichoderma harzianum and T. viride. The inoculated Petri plates were incubated for 7 days at $27 \pm 2{ }^{0} \mathrm{C}$. After incubation, radial growth was measured and Per cent growth inhibition was calculated by applying the formula (Vincent, 1947).
Per cent inhibition $=\frac{\text { C-T }}{\text { C }}$

Where,

$\mathrm{C}=$ Growth of test fungus in control in $\mathrm{mm}$

$\mathrm{T}=$ Growth of test fungus in treatment in $\mathrm{mm}$

Screening of Pseudomonas fluorescens with fungicides

For studying compatibility of Pseudomonas fluorescens with four fungicides viz., Thiram @0.3\%, Carbendazim@0.1\%, Captan @ $0.3 \%$ and fosetyl AL @0.2\%, firstly, pour Petri plates with nutrient agar media (Mohiddin et al., 2013) as a control in half portion of Petri plate and allow to solidify. Then pour nutrient agar mixing with different fungicides at particular concentration in remaining half portion of plate and solidified. After that bacterial culture were streaks in such a manner that bacteria would get equal opportunity on both side media for their growth and incubate plate for 2-3 days and observed the growth inhibition of bacteria.

\section{Results and Discussion}

Based on In vitro evaluation of Trichoderma species with the 4 fungicides, the result in table 1 and figure 1 concluded that the $T$. viride was compatible with Fosetyl AL $(0.2 \%)$ by showing the lowest per cent growth inhibition 57.59\%. Whereas maximum $(100 \%)$ growth inhibition was observed with Thiram $(0.3 \%)$ and Carbendazim $(0.1 \%)$ at 7 DAI.

The result in table 2 and figure 2 indicated that growth of Trichoderma harzianum was compatible with Fosetyl AL $(0.2 \%)$ by showing the lowest per cent growth inhibition $1.3 \%$. Whereas maximum inhibition with Carbendazim $(0.1 \%)$ at 7 DAI. 
The result presented in figure 3 showed that Pseudomonas fluorescens was found more compatible with Carbendazim $(0.1 \%)$ and
Fosetyl Al (0.2\%) and non-compatible with Captan $(0.3 \%)$ and Thiram $(0.3 \%)$.

Table.1 Compatibility of Trichoderma viride with fungicides

\begin{tabular}{|c|c|c|c|c|}
\hline Treatments & Fungicide & Concentration & $\begin{array}{c}\text { Mean colony } \\
\text { diameter } \\
(\mathbf{m m})\end{array}$ & $\begin{array}{c}\text { Per cent } \\
\text { growth } \\
\text { inhibition }\end{array}$ \\
\hline $\mathrm{T}_{1}$ & Thiram & $0.3 \%$ & 0 & $\begin{array}{c}100 \\
(90.00)^{*}\end{array}$ \\
\hline $\mathrm{T}_{2}$ & $\begin{array}{c}\text { Carbendazim } \\
50 \% \mathrm{WP}\end{array}$ & $0.1 \%$ & 0 & $\begin{array}{c}100 \\
(90.00)^{*}\end{array}$ \\
\hline $\mathrm{T}_{3}$ & $\begin{array}{c}\text { Captan } \\
50 \% \mathrm{WP}\end{array}$ & $0.3 \%$ & 13.33 & $\begin{array}{c}85.18 \\
(67.36)^{*}\end{array}$ \\
\hline $\mathrm{T}_{4}$ & $\begin{array}{c}\text { Fosetyl AL } \\
80 \% \mathrm{WP}\end{array}$ & $0.2 \%$ & 38.17 & $\begin{array}{c}57.59 \\
(49.37)^{*}\end{array}$ \\
\hline $\mathrm{T}_{5}$ & Control & & 90 & 0.00 \\
\hline $\mathrm{F}$ test & & & & $\mathrm{Sig}$ \\
\hline $\mathrm{SE}(\mathrm{m}) \pm$ & & & & $\mathbf{0 . 3 1 4}$ \\
\hline $\mathrm{CD}(\mathrm{P}=0.01)$ & & & & $\mathbf{2 . 6 6 6}$ \\
\hline
\end{tabular}

(*=Figures in parentheses indicates arc sin transformed value)

Table.2 Compatibility of Trichoderma harzianum with fungicides

\begin{tabular}{|c|c|c|c|c|}
\hline Treatments & Fungicide & Concentration & $\begin{array}{c}\text { Mean colony } \\
\text { diameter } \\
(\mathbf{m m})\end{array}$ & $\begin{array}{c}\text { Per cent } \\
\text { growth } \\
\text { inhibition }\end{array}$ \\
\hline $\mathrm{T}_{1}$ & Thiram & $0.3 \%$ & 52.47 & $\begin{array}{c}41.70 \\
(40.22)^{*}\end{array}$ \\
\hline $\mathrm{T}_{2}$ & $\begin{array}{c}\text { Carbendazim } \\
50 \% \text { WP }\end{array}$ & $0.1 \%$ & 0 & $\begin{array}{c}100 \\
(90.00)^{*}\end{array}$ \\
\hline $\mathrm{T}_{3}$ & $\begin{array}{c}\text { Captan } \\
50 \% \text { WP }\end{array}$ & $0.3 \%$ & 44.70 & $\begin{array}{c}50.33 \\
(45.19)^{*}\end{array}$ \\
\hline $\mathrm{T}_{4}$ & $\begin{array}{c}\text { Fosetyl AL } \\
80 \% \mathrm{WP}\end{array}$ & $0.2 \%$ & 88.83 & $\begin{array}{c}1.3 \\
(6.55)^{*}\end{array}$ \\
\hline $\mathrm{T}_{5}$ & Control & & 90 & 0.00 \\
\hline $\mathrm{F}$ test & & & & $\mathrm{Sig}$ \\
\hline $\mathrm{SE}(\mathrm{m}) \pm$ & & & & $\mathbf{0 . 2 0 1}$ \\
\hline $\mathrm{CD}(\mathrm{P}=0.01)$ & & & & $\mathbf{1 . 7 0 2}$ \\
\hline
\end{tabular}

$(*=$ Figures in parentheses indicates arc sin transformed value) 
Figure.1 Compatibility of Trichoderma viride with fungicides

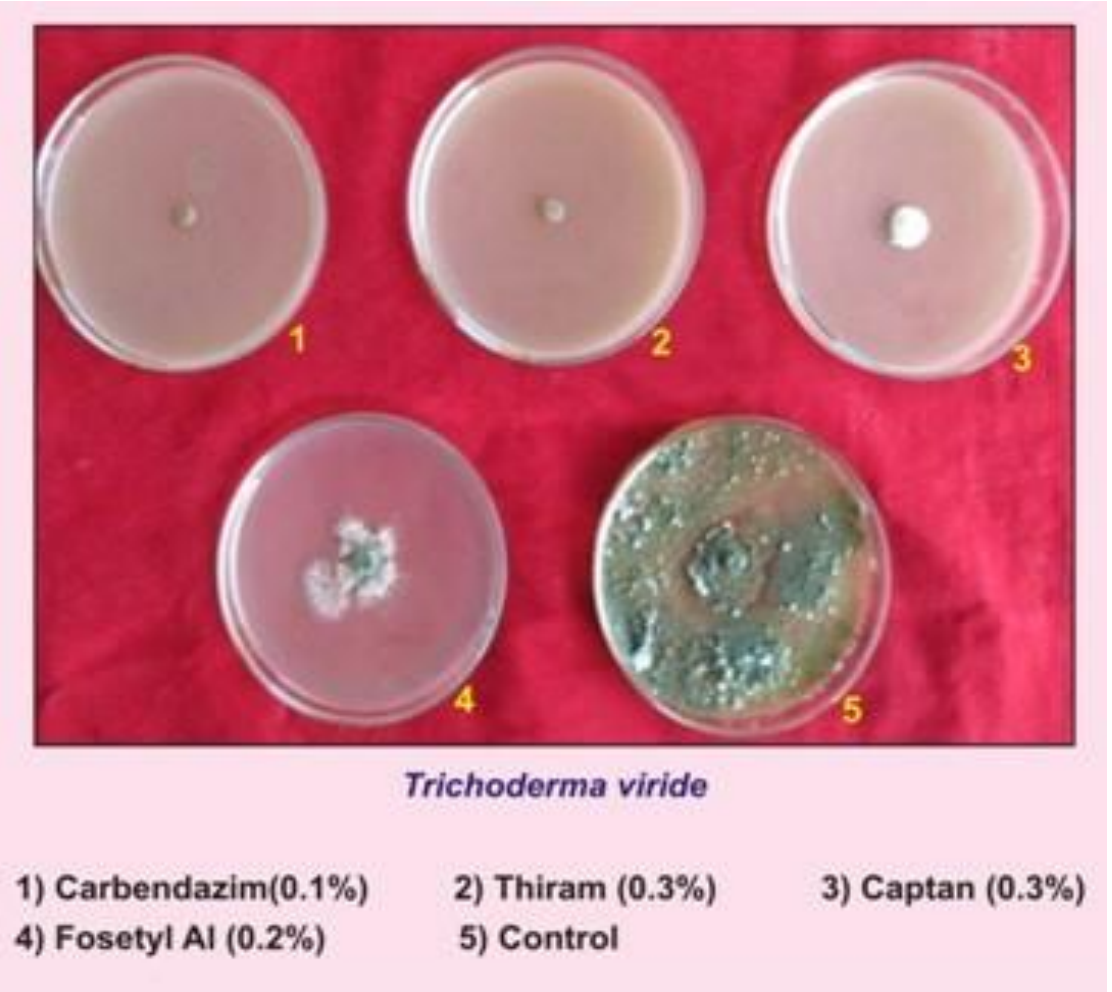

Figure.2 Compatibility of Trichoderma harzianum with fungicides

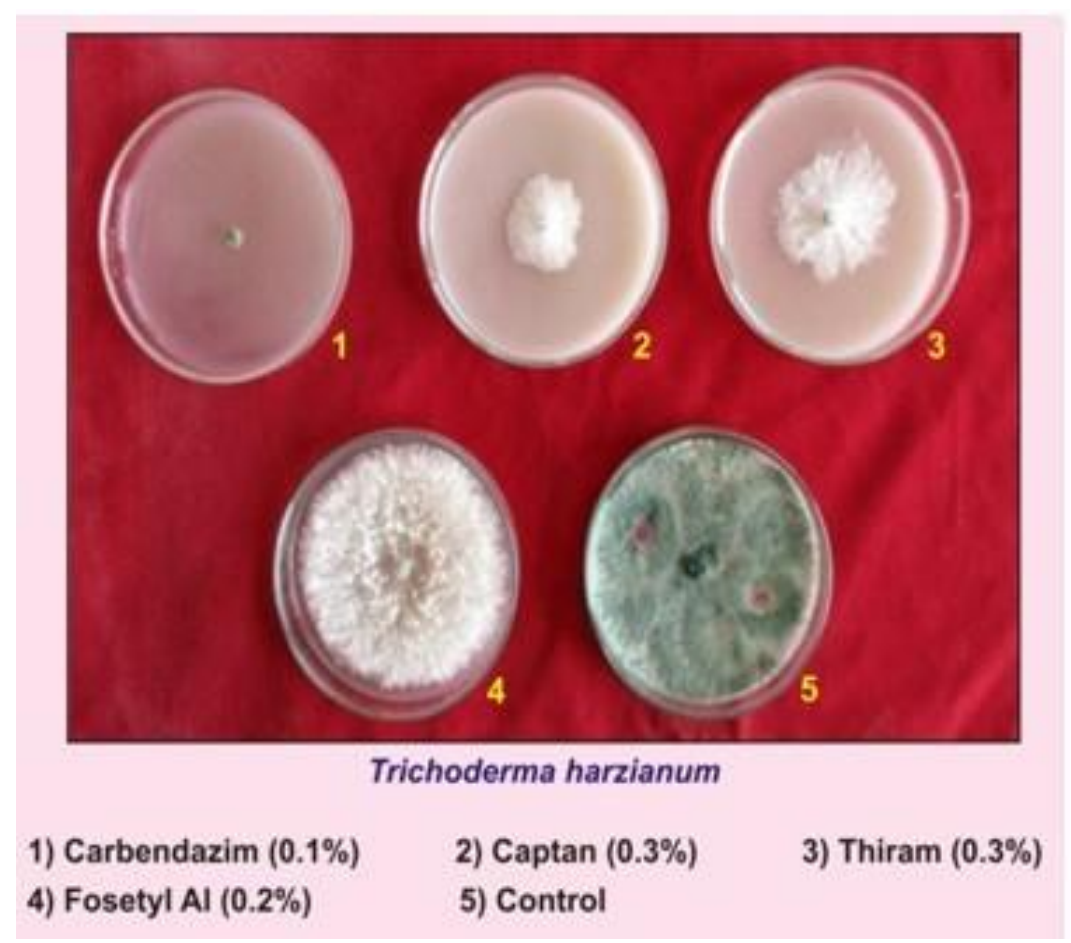


Figure.3 Compatibility of Pseudomonas fluorescens with fungicides



The compatibility test of Trichoderma spp. revealed that the $T$. viride and $T$. harzianum, both species were more sensitive to Carbendazim $(0.1 \%)$ and showing more tolerance with Fosetyl AL (0.2\%) compared to other fungicides used in the study. Similar results have been obtained by other workers. Upadhyay et al., (2004) found that Bavistin (@25 g/ml) resulted complete inhibition of growth and sporulation of Trichoderma viride In vitro. Thoudam and Dutta (2014) found the radial mycelial growth of Trichoderma was $100 \%$ inhibited in Carbendazim. Sharma et al., (2001) found that, T. harzianum is sensitive to carbendazim. The biocontrol bacteria viz., Pseudomonas fluorescens was found more tolerant to fungicide Carbendazim $(0.1 \%)$ and Fosetyl Al (0.2\%).This may be due to the reason that, some bacteria can use pesticides as nutrients and hence can tolerate (Kishore and Jacob, 1987; Aislabie and Jones, 1995). This finding supports the earlier findings of Telangre et al., (2013) that Carbendazim was compatible with $P$. fluorescens and Carbendazim @ 0.05 and 0.1 per cent each favored the growth of Pseudomonas fluorescens. Fungicides those are inhibitory against a narrow spectrum of plant pathogen but not against biocontrol agent offer a chance for integration of chemical and biocontrol agents. The present study clearly demonstrated that, soil borne plant pathogens can be successfully managed by combined application of biocontrol agents with cheap fungicides like carbendazim, Fosetyl Al etc. commonly used by farmers in India at low doses. Also pesticide residues in soil will not affect the biocontrol agent effectiveness and hence can be easily applied in integration with the pesticides for the control of soil borne plant pathogens.

\section{References}

Aislabie, J. and Jones, L.G. 1995. A review of bacterial degradation of pesticides. Austr. J. Soil Res., 33: 925-942.

Baker, K.F. and Cooke, R.J. 1974. Biological control of plant pathogens, W.H. Freeman Press, San Fransisco.

Buck, J.W. 2004. Combination of fungicides with phylloplane yeasts for improved control of Botrytis cinerea on geranium seedlings. Phytopathol., 94:196-202.

Campbell, R. 1989. Biological Control of Microbial Plant Pathogens. Cambridge 
University Press, Cambridge.

Cook, R.J. and Baker, K.F. 1983. The Nature and Practice of Biological Control of Plant Pathogens, American Phytopathological Society, St. Paul, MN.

Dluzneiwska, J. 2003. Reaction of fungi of Trichoderma genus to selected abiotic factors. Elec. J. Polish Agr. Uni. Agron, 6(2): 239-242.

Federico, G.R., Maria, M.R., Marcela, F., Sofía, N.C. and Adriana, M.T. 2007. Biological control by Trichoderma species of Fusarium solani causing peanut brown root rot under field conditions, Crop Protect., 26: 549-555.

Frances, J., Vilardell, P., Bonaterra, A., Badosa, E. and Mantesinos, E. 2002. Combination of Pseudomonas fluorescens EPS288 and reduced fungicide dose for control of Penicillium rot during post harvest storage of pear. Acta Hortic., 596: 883886.

Kishore, G.M. and Jacob, G.S. 1987. Degradation of glyphosate by Pseudomonas spp. PG2982 via a sarcosine intermediate, J. Biol. Chem., 262: 12164-12168.

Mohiddin, F.A. and Khan, M.R. 2013. Tolerance of fungal and bacterial biocontrol agents to six pesticides commonly used in the control of soil borne plant pathogens. African J. Agric. Res., 8(43): 5331-5334.

O'Sullivan, D.J. and O'Gara, F. 1992. Traits of fluorescent Pseudomonas spp. involved in suppression of plant root pathogens. Microbiol. Rev., 56: 662672.

Sahebani, N. and Hadavi, N. 2008. Biological control of the root knot nematode Meloidogyne javanica by Trichoderma harzianum. Soil Biol. Biochem., 40: 2016-2020.

Telangre, R.D., Mane, S.S. and Ghawade, R.S. 2013. Efficacy and Compatibility of Pseudomonas fluorescens with fungicides in management of pigeonpea wilt. J. Pl. Dis. Sci., 8(1): 33-36.

Thoudam, R. and Dutta, B.K. 2014. Compatibility of Trichoderma atroviride with fungicides against black rot disease of tea: an in vitro study. $J$. Inter. Acad. Res. Multi., 2(2): 23205083.

Upadhyay, J.P., Lal, H.C. and Roy, S. 2004. Effect of Fungicide, Cakes and Plant Byproduct on Trichoderma viride. J. Mycol. Pl. Pathol., 34: 2.

Vidhyasekaran, P., Rabindran, R., Muthamilan, M., Nayar, K., Rajappan, K., Subramanian, N. and Vasumathi, K. 1997. Development of powder formulation of Pseudomonas fluorescens for control of rice blast. Plant Pathol., 46: 291-297.

Vincent, J.M. 1947. Distoration of fungal hyphae in the presence of certain inhibitors. Nature, 15: 850.

Weller, D. 1988. Biological control of soil borne plant pathogens in the rhizosphere with bacteria. Annu. Rev. Phytopathol., 26: 379-407.

\section{How to cite this article:}

Praful Kumar and Mane, S.S. 2017. Studies on the Compatibility of Biocontrol Agents with Certain Fungicides. Int.J.Curr.Microbiol.App.Sci. 6(3): 1639-1644. doi: https://doi.org/10.20546/ijcmas.2017.603.189 